\title{
Concomitant herpes-like virus infections in hatchery-reared larvae and nursery-cultured spat Crassostrea gigas and Ostrea edulis
}

\author{
Tristan Renault*, Rose-Marie Le Deuff, Bruno Chollet, Nathalie Cochennec, \\ André Gérard
}

Institut Français de Recherche pour l'Exploitation de la Mer, Laboratoire de Génétique et Pathologie, BP 133, 17390 La Tremblade, France

\begin{abstract}
Concomitant sporadic high mortalities were reported in France in May 1994 among batches of hatchery-reared larval Pacific oysters Crassostrea gigas and European flat oysters Ostrea edulis in 2 hatcheries, and in June and July 1994 among batches of cultured spat of both species in a shellfish nursery. Histological observation showed the presence of cellular abnormalities in moribund animals. Transmission electron microscopy revealed the presence of herpes-like virus particles in infected larvae and spat of both oyster species. This is the first description of a herpes-like virus infection in larval $O$. edulis. Viruses observed in diseased larvae and spat of both species are similar with respect to ultrastructure and morphogenesis. They were detected simultaneously in C. gigas and $O$. edulis larvae and spat, indicating possible interspecific transmission. Moreover, these viruses are associated with high mortality rates in both oyster species. An electron microscopic examination revealed hemocytes with condensed chromatin and extensive perinuclear fragmentation of chromatin. These data suggest that herpes-like viruses infecting oysters may induce apoptosis in oyster hemocytes.
\end{abstract}

KEY WORDS: Herpes-like virus $\cdot$ European flat oyster $\cdot$ Ostrea edulis $\cdot$ Pacific oyster $\cdot$ Crassostrea gigas $\cdot$ Oyster mortality $\cdot$ Concomitant infection $\cdot$ Virus replication $\cdot$ Apoptosis

\section{INTRODUCTION}

A herpes-like virus infection which was asssociated with mortalities among larvae of hatchery-reared Pacific oyster Crassostrea gigas was reported for the first time in France during summer 1991 (Nicolas et al. 1992). Since this first description, further outbreaks of herpes-like virus infections have been regularly noted among Pacific oyster larvae during the summer period each year in some French hatcheries (Renault et al. 1994a). Moreover, during summer of 1993, 1994 and 1995, sporadic high mortalities occurred in some batches of Pacific oyster spat cultured in different

*E-mail: trenault@ifremer.fr
French locations (Renault et al. 1994b, unpubl. data). A herpes-like virus was reported in association with mortalities among Ostrea edulis spat originating from Brittany in France (Comps \& Cochennec 1993). In austral mid-summer 1991, Hine et al. (1992) described a herpes-like virus infection responsible for high mortality of hatchery-reared C. gigas larvae in New Zealand. More recently, herpes-like viruses have been observed in hemocytes of $O$. angasi adults in Australia (Hine \& Thorne 1997) and in larval New Zealand flat oysters Tiostrea chilensis, resulting in high mortality rates (Hine et al. 1998). All these viruses are similar with respect to morphology, cellular localizations and apparent tropism. Viruses observed in France among Pacific oyster larvae and spat are similar in size (Renault et al. 1994b), but they are smaller than the 
viral particles reported by Hine et al. (1992) in New Zealand and the virus-like particles described by Comps \& Cochennec (1993) among French cultured European flat oyster spat.

We describe for the first time a herpes-like virus infecting European flat oyster larvae and concomitant herpes-like virus infections associated with high mortalities among hatchery-reared larvae and nurserycultured spat of both Crassostrea gigas and Ostrea edulis during the summer of 1994 in France. We performed an ultrastructural comparative study between both virus-like particles found respectively in Pacific oysters and European flat oysters and compared them to viruses belonging to the Herpesviridae family.

\section{MATERIALS AND METHODS}

Specimens. Larval Ostrea edulis and Crassostrea gigas, 6 to $10 \mathrm{~d}$ old, 80 to $150 \mu \mathrm{m}$ in size, were collected in May 1994 from 2 hatcheries located in Bourgneuf Bay (Vendée, France). Nursery-cultured spat of $C$. gigas and $O$. edulis, 3 to 5 mo old, were also collected from Bourgneuf Bay in June and July 1994.

Light microscopy. A total of 197 European flat oyster spat and 196 Pacific oyster spat were collected for light microscopical examination. Moribund cultured spat of both species, 3 to 5 mo old, were removed from the shell and, sagittally sectioned; then half of each specimen was fixed in Davidson's fixative for light microscopic examination and the other half in Carson's fixative for transmission electron microscopic analysis. After $48 \mathrm{~h}$ fixation in Davidson's fluid, samples were dehydrated using an ascending ethanol series, cleared in xylene and infiltrated with paraffin. They were then embedded in paraffin and sectioned at $3 \mu \mathrm{m}$ thickness. After dewaxing, tissue sections were stained with Hematoxylin and Eosin (HE) for routine examination, and Feulgen's stain for DNA (Gabe 1968).

Eighteen batches of moribund larvae were directly fixed in glutaraldehyde for light and transmission electron microscopy.

Electron microscopy. For transmission electron microscopy, fresh infected larvae or gill, mantle and digestive gland fragments of diseased spat previously fixed in Carson's fluid were transferred in cold 2.5\% glutaraldehyde in $0.2 \mathrm{M}$ cacodylate buffer at $\mathrm{pH} 7.2$ for $1 \mathrm{~h}$. Specimens taken from tissues stored in Carson's fixative were rinsed for $48 \mathrm{~h}$ in $0.2 \mathrm{M}$ cacodylate buffer at $4{ }^{\circ} \mathrm{C}$ before fixation in glutaraldehyde. Samples were then post-fixed in $1 \%$ osmium tetroxide in the same buffer at $4^{\circ} \mathrm{C}$. Larval samples were dehydrated by serial ethanol baths (70 to $100 \%$ ), partially rehyrated by two 10 min baths in cacodylate buffer and de-calcified with a $2 \%$ ethylene-tetra- acetic acid (EDTA) solution in $0.2 \mathrm{M}$ cacodylate buffer overnight at $4^{\circ} \mathrm{C}$. After fixation and post-fixation, larvae and spat specimens were washed in $0.2 \mathrm{M}$ cacodylate buffer, dehydrated by means of an ascending ethanol series ( 70 to $100 \%$ ), cleared twice for $15 \mathrm{~min}$ in propylene oxide and infiltrated for $1 \mathrm{~h}$ in 50:50 propylene oxide:Epon resin. After $1 \mathrm{~h}$ infiltration in pure Epon resin, they were embedded in resin and cured for $48 \mathrm{~h}$ at $60^{\circ} \mathrm{C}$. Sections $(1 \mu \mathrm{m})$ for light microscopic examination were stained in $0.5 \%$ toluidine blue in $1 \%$ sodium borate solution. Ultrathin sections were stained in 5\% uranyl acetate in $50 \%$ ethanol for $20 \mathrm{~min}$ and in $5 \%$ lead citrate in fresh boiled distilled water for $3 \mathrm{~min}$. They were examined in a JEOL JEM 1200 EX transmission electron microscope at $80 \mathrm{kV}$.

\section{RESULTS}

\section{Course of the disease}

A few days after being spawned, larvae of both Crassostrea gigas and Ostrea edulis showed a reduction in feeding and swimming activities in batches from 2 French hatcheries (Bourgneuf Bay, Vendée, France). High mortality occurred, at the beginning of May 1994, by Day 6, with total mortality by Days 8 to 10 . Moribund larvae swam weakly in circles with their vela noticeably less extended than in healthy larvae. They exhibited velar lesions and some free pieces of velum were also observed in the tank water. Moribund larvae measured 80 to $150 \mu \mathrm{m}$. Mortalities were first observed in European flat oyster larvae and a few days afterward in Pacific oysters in both hatcheries.

For spat of both species Crassostrea gigas and Ostrea edulis, mortalities occurred at the beginning of June 1994 in a nursery from the Bay of Bourgneuf (Vendée, France). Sudden and high mortalities occurred first in some batches of Pacific oyster spat and reached $70 \%$ within $5 \mathrm{~d}$. High mortalities (50\%) also occurred in the same nursery among some batches of European flat oyster spat. They occurred $1 \mathrm{wk}$ after the mortalities in C. gigas spat. After $1 \mathrm{mo}$, all batches of both species were affected and mortalities reached 90 to $95 \%$.

\section{Histological examination}

Changes were noted in semi-thin sections of diseased larvae for all examined batches in both oyster species. Histologically, the lesions appeared to be confined to connective tissue. Fibroblastic-like cells exhibited an abnormal cytoplasmic basophilia and enlarged nuclei with marginated chromatin; other 
cells believed to be hemocytes showed extensive chromatin condensation (Fig. 1).

The main histological change in spat of both oyster species was the presence of abnormal nuclei throughout connective tissue, especially in the mantle, labial palps and digestive gland connective tissue. There was no noticeable difference in the appearence of affected tissues between infected European flat oysters and infected Pacific oysters or between larvae and spat of both oyster species. Abnormalities consisted of enlarged nuclei associated with abnormal marginated chromatin in fibroblastic-like cells and highly condensed nuclei in ovoid cells interpreted as hemocytes. Some nuclei showed peculiar patterns of chromatin with a characteristic ring-shape or crescent-shape. This type of chromatin abnormality was more rarely seen in infected Japanese oysters than in infected European flat oysters. Feulgen's stain confirmed the presence of DNA in nuclear abnormalities from Crassostrea gigas and Ostrea edulis. These abnormalities in both oyster species were not associated with a massive inflammatory reaction. Necrosis of the neighbouring digestive tubule, mantle and labial palp epithelia was rarely detected. Ninety-two European flat oysters $(47 \%)$ and 119 Japanese oysters (61\%) examined showed abnormal nuclei in the connective tissue of various organs (mantle, labial palps and digestive gland).

\section{Electron microscopical examination}

The basophilic fibroblastic-like cells in infected larvae showed hypertrophied nuclei and marginated chromatin in both oyster species (Fig. 2). The previously described
Table 1. Morphological characteristics of herpes-like virus particles observed in both Crassostrea gigas and Ostrea edulis at several developmental stages

\begin{tabular}{|lccc|}
\hline Host species & \multicolumn{3}{c|}{ Size (in $\mathrm{nm})(\mathrm{n}=25)$} \\
& Capsids & Nucleocapsids Enveloped virions \\
\hline C. gigas larvae & $81 \pm 5$ & $75 \pm 4$ & $117 \pm 5$ \\
C. gigas spat & $84 \pm 3$ & $77 \pm 3$ & $116 \pm 5$ \\
O. edulis larvae & $85 \pm 5$ & $76 \pm 4$ & $118 \pm 8$ \\
O. edulis spat & $85 \pm 3$ & $75 \pm 3$ & $109 \pm 8$ \\
\hline
\end{tabular}

patterns of chromatin were observed by electron microscopy in affected Crassostrea gigas and Ostrea edulis spat (Fig. 3). Some nuclei were electron dense and showed crescent-shaped condensation of the chromatin (Fig. 4). This type of abnormality was more often observed in infected $O$. edulis oysters than in $C$. gigas oysters. Cell shrinkage was associated with large amounts of condensed chromatin in the hemocytes (Fig. 5) and highly condensed electron-dense cytoplasm (Fig. 5).

Fibroblastic-like cells in larvae and spat of both oyster species contained intranuclear virus-like particles (Fig. 6). The nuclear particles were circular or polygonal in shape, 71 to $80 \mathrm{~nm}$ in diameter in infected Japanese oysters and 72 to $80 \mathrm{~nm}$ in diameter in infected European flat oysters (Table 1). In both species, some nuclear particles appeared empty and were interpreted as being capsids, others contained an electron-dense toroidal or brick-shaped core and were presumed to be nucleocapsids (Fig. 6). Capsids and nucleocapsids were scattered throughout the nucleus of infected cells (Fig. 6). Nucleoid acquisition was observed in infected nuclei of $C$. gigas and $O$. edulis spat
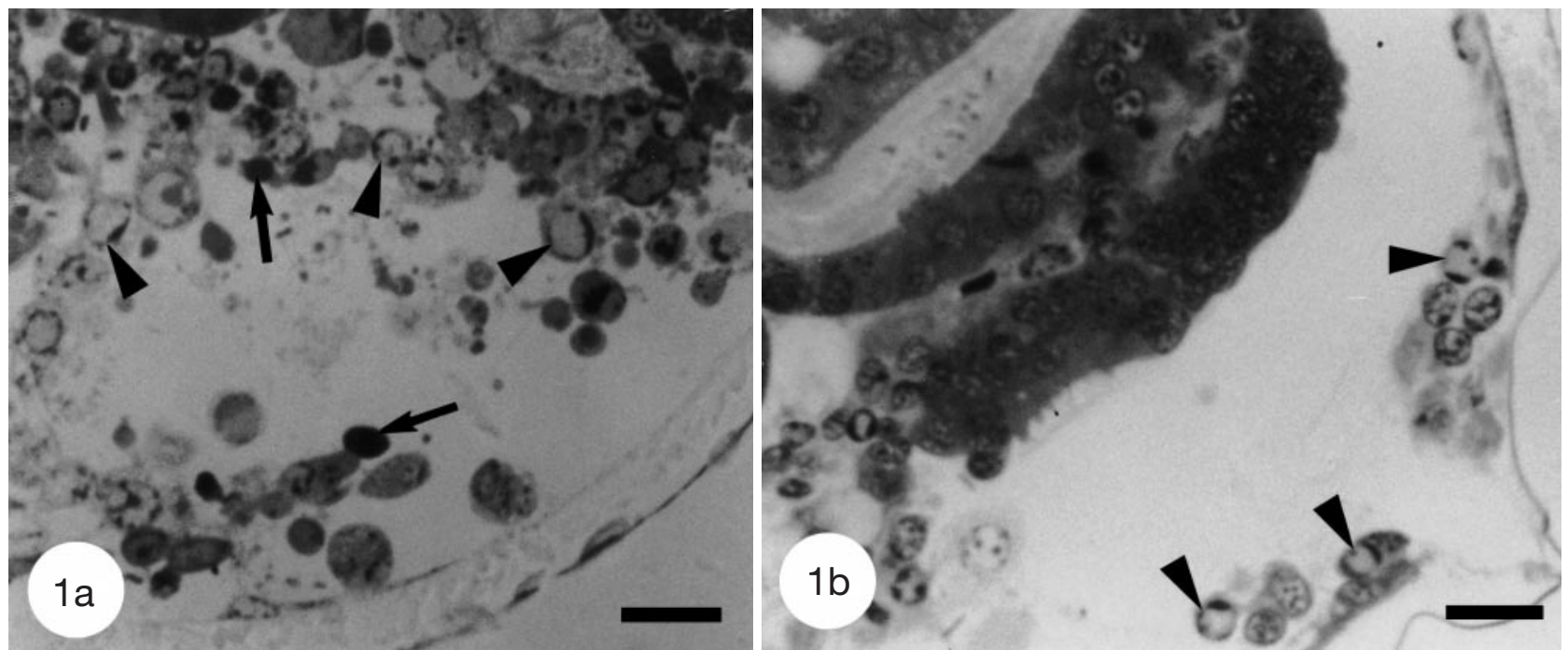

Fig. 1. Semithin sections stained with toluidine blue showing abnormal cells with condensed nuclei (arrows) and chromatin margination (arrowheads). Scale bars $=10 \mu \mathrm{m}$. (a) Larval Crassostrea gigas. (b) Larval Ostrea edulis 

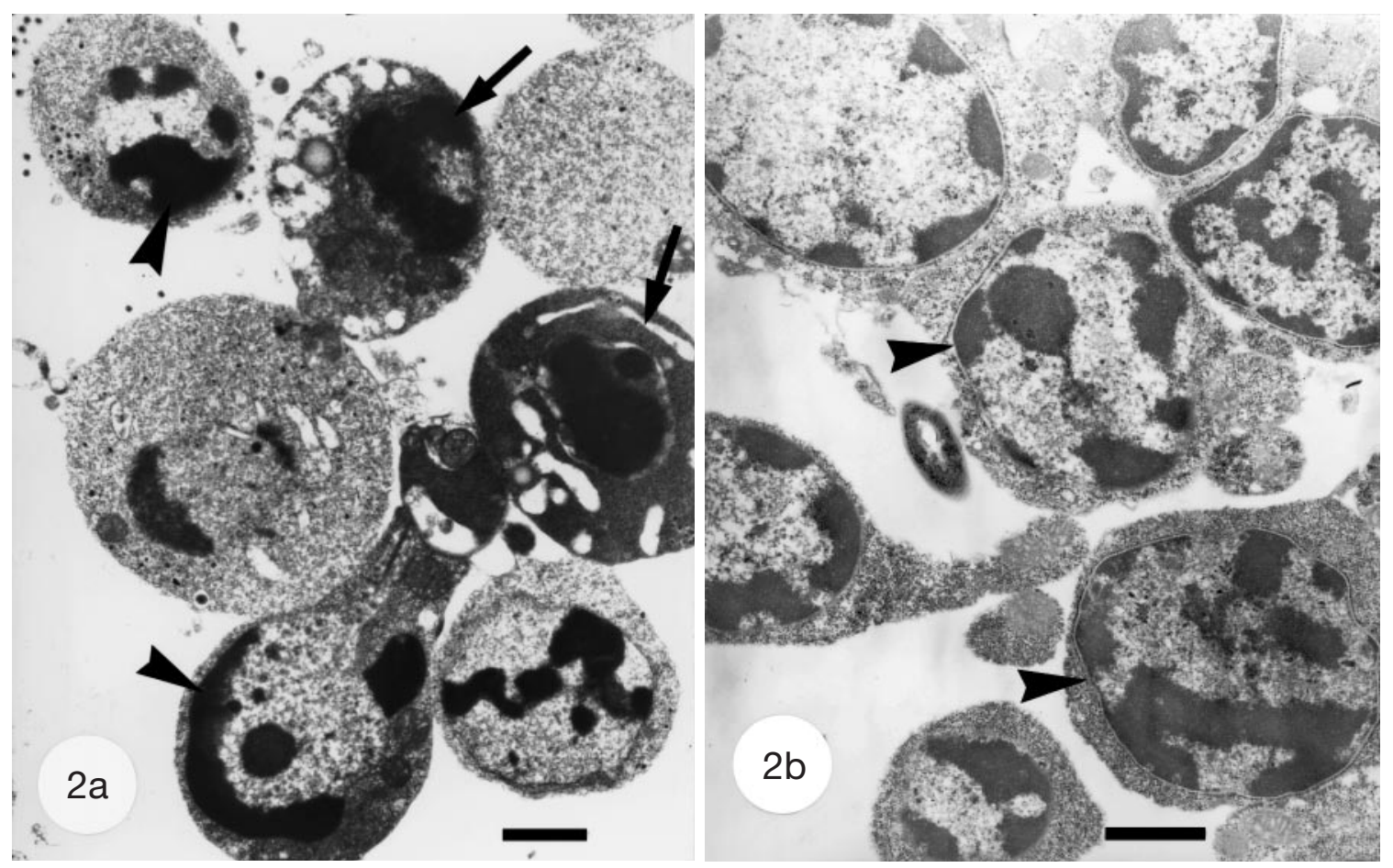

Fig. 2. Transmission electron micrographs of connective tissue showing condensed nuclei (arrows) and chromatin margination (arrowheads). (a) Crassostrea gigas larva, scale bar $=1 \mu \mathrm{m}$. (b) Ostrea edulis larva, scale bar $=1 \mu \mathrm{m}$
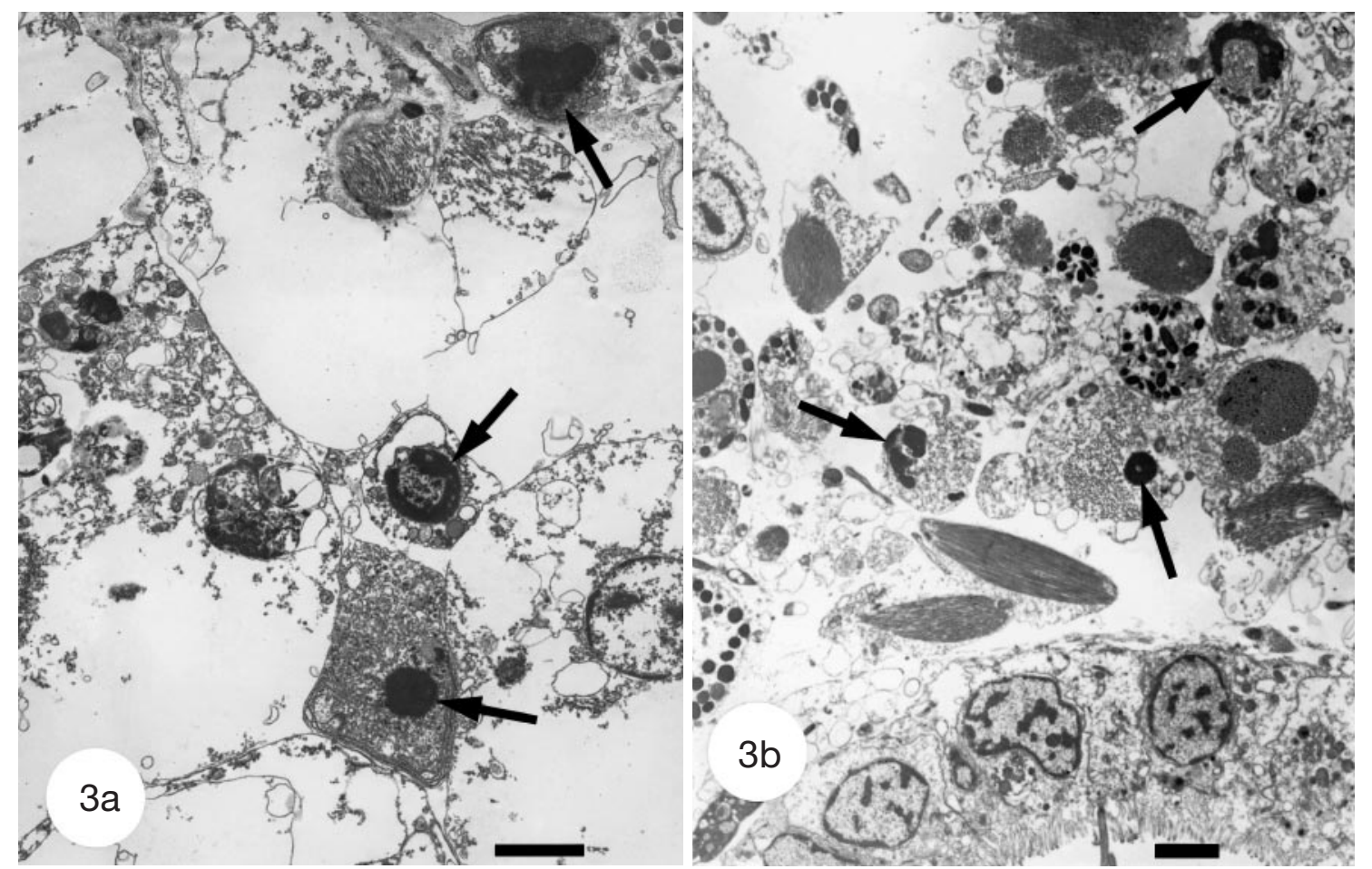

Fig. 3. Transmission electron micrographs of mantle connective tissue showing condensed nuclei, chromatin margination and abnormal nuclei with a ring-shaped chromatin pattern (arrows). (a) Crassostrea gigas spat, scale bar = $2 \mu \mathrm{m}$. (b) Ostrea edulis spat, scale bar $=2 \mu \mathrm{m}$ 

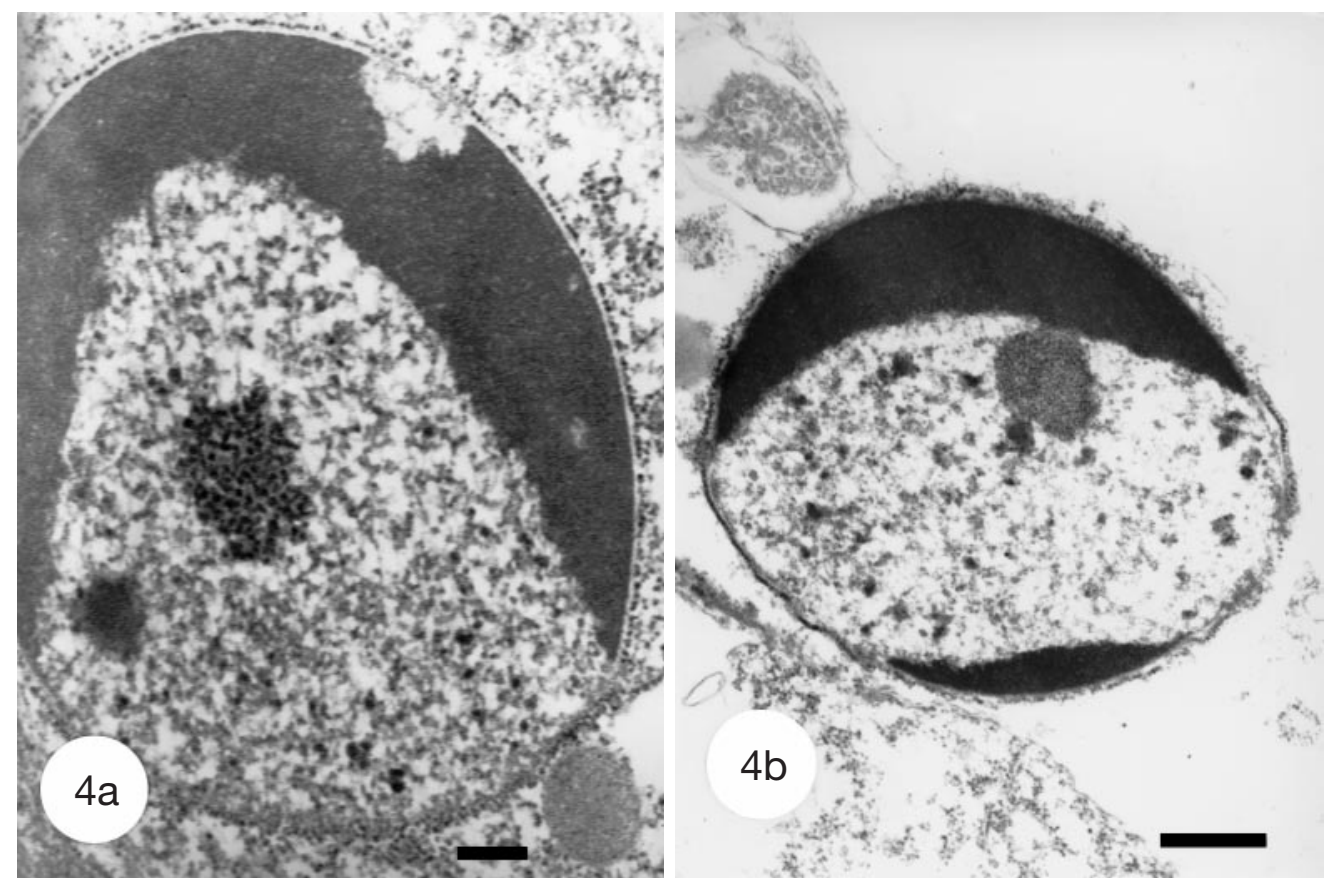

Fig. 4. Abnormal nuclei with a crescent-shaped condensation of the chromatin. (a) Ostrea edulis larvae, scale bar $=500 \mathrm{~nm}$. (b) Ostrea edulis spat, scale bar $=200 \mathrm{~nm}$

in association to fibril structures (Fig. 7). Enveloped single virions or groups of virus particles were frequently observed in cytoplasmic vesicles. These intracytoplasmic particles possessed an envelop formed by a trilaminar unit-membrane. They contained identically shaped and sized elements, with the same structures as the nuclear particles. Envelope and capsid were separated by an electron-lucent gap of approximately $5 \mathrm{~nm}$ with fine fibrils spanning the lucent-space from core to capsid. Naked nucleocapsids were also observed free in the cytoplasm of infected cells. Extracellular viruses were usually enveloped and measured 100 to $130 \mathrm{~nm}$ in diameter in both oyster species (Table 1). No or a reduced tegument was observed between the outer membrane and the capsid shell of enveloped particles in both infected oyster species (Fig. 8). Nucleocapsids also occurred in myocytes (Fig. 9) and a few hemocytes contained viral particles.
Fig. 5. Condensed nuclei in oyster hemocytes. (a) Crassostrea gigas larvae, scale bar $=1 \mu \mathrm{m}$. (b) Crassostrea gigas spat, scale bar $=2 \mu \mathrm{m}$
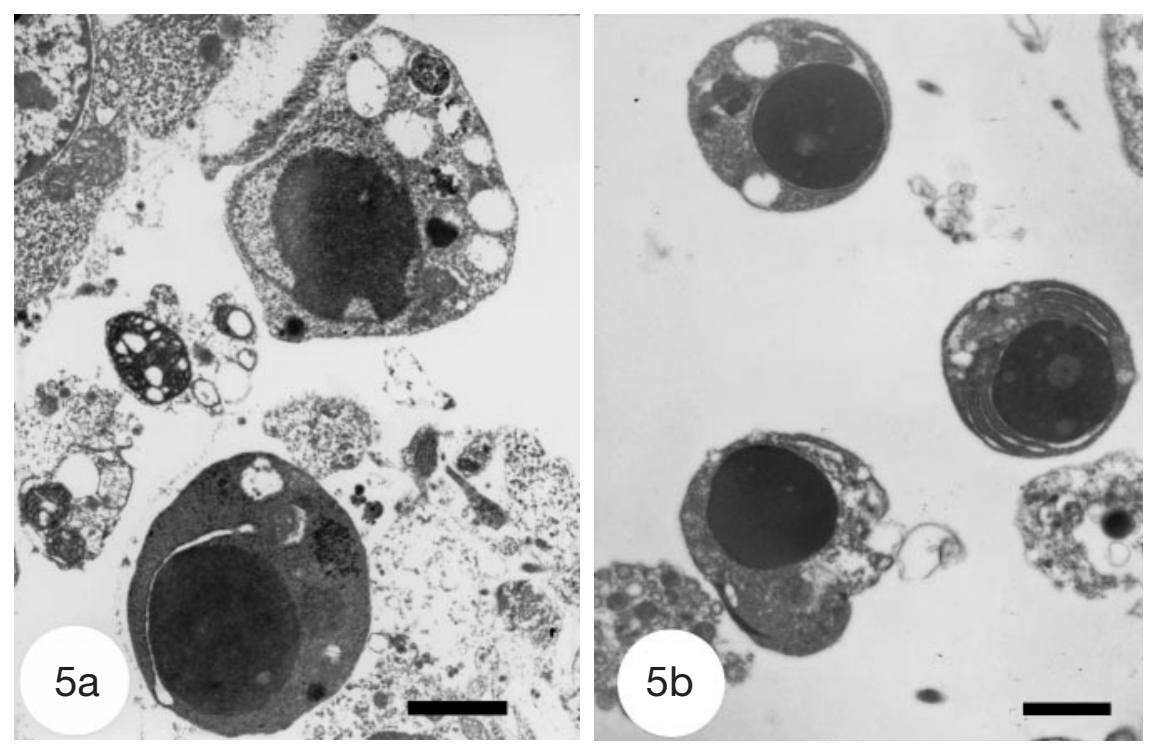

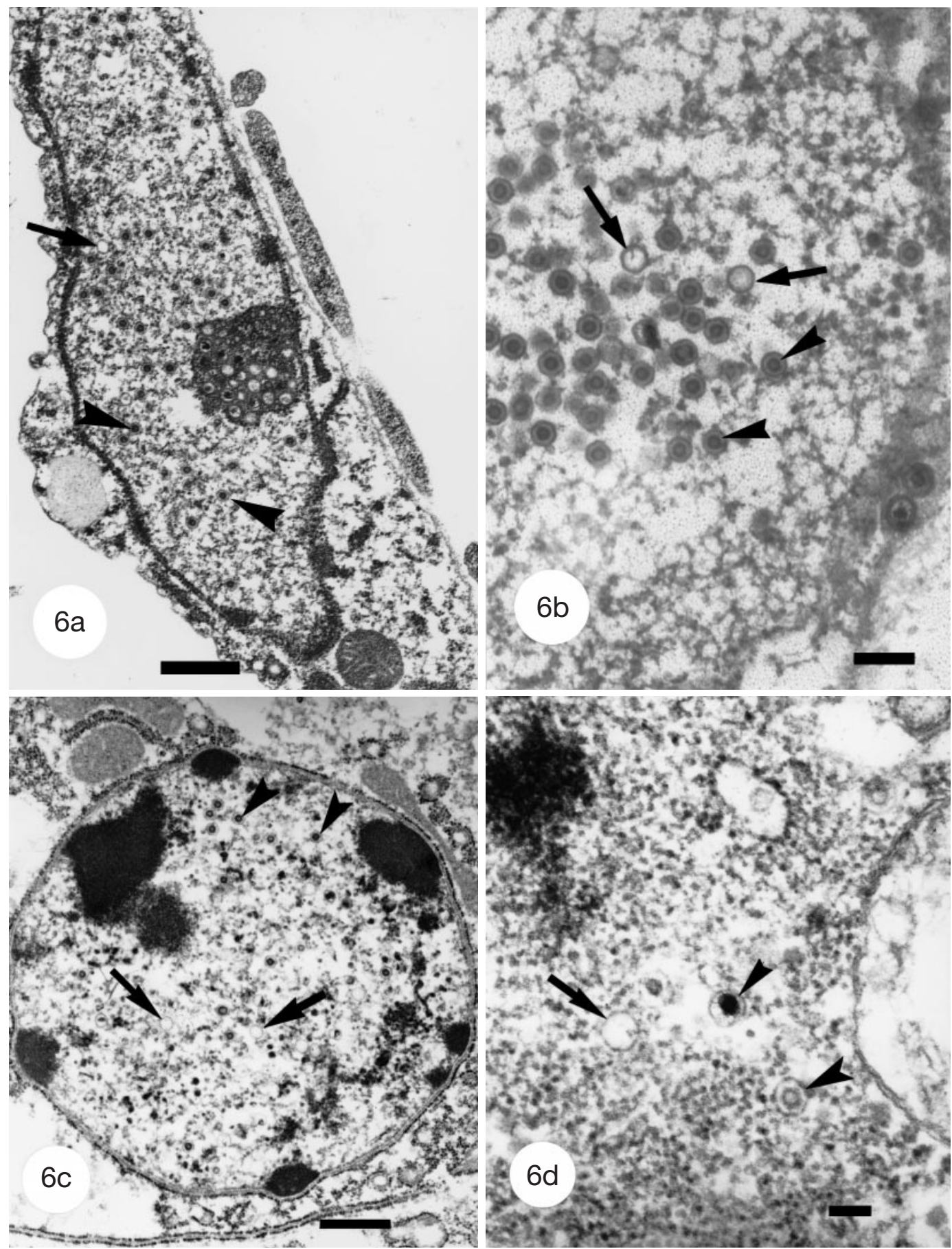

Fig. 6. Nuclei of infected fibroblastic-like cells containing empty capsids (arrows) and nucleocapsids (arrowheads). (a) Crassostrea gigas larva, scale bar $=500 \mathrm{~nm}$. (b) Crassostrea gigas spat, scale bar $=200 \mathrm{~nm}$. (c) Ostrea edulis larva, scale bar $=100 \mathrm{~nm}$.

(d) Ostrea edulis spat, scale bar $=100 \mathrm{~nm}$

Abnormal accumulations of granular endoplasmic reticulum were often observed in affected tissues among infected Crassostrea gigas and more rarely among diseased Ostrea edulis spat (Fig. 10). The occasional occurrence of nuclear tubular structures 45 to
$55 \mathrm{~nm}$ in diameter with a helical substructure was reported (Fig. 11). Transverse sections of tubular structures showed a tube within a tube arrangement similar in appearance to capsids with lucent cores, which were usually abundant near tubular structures. 

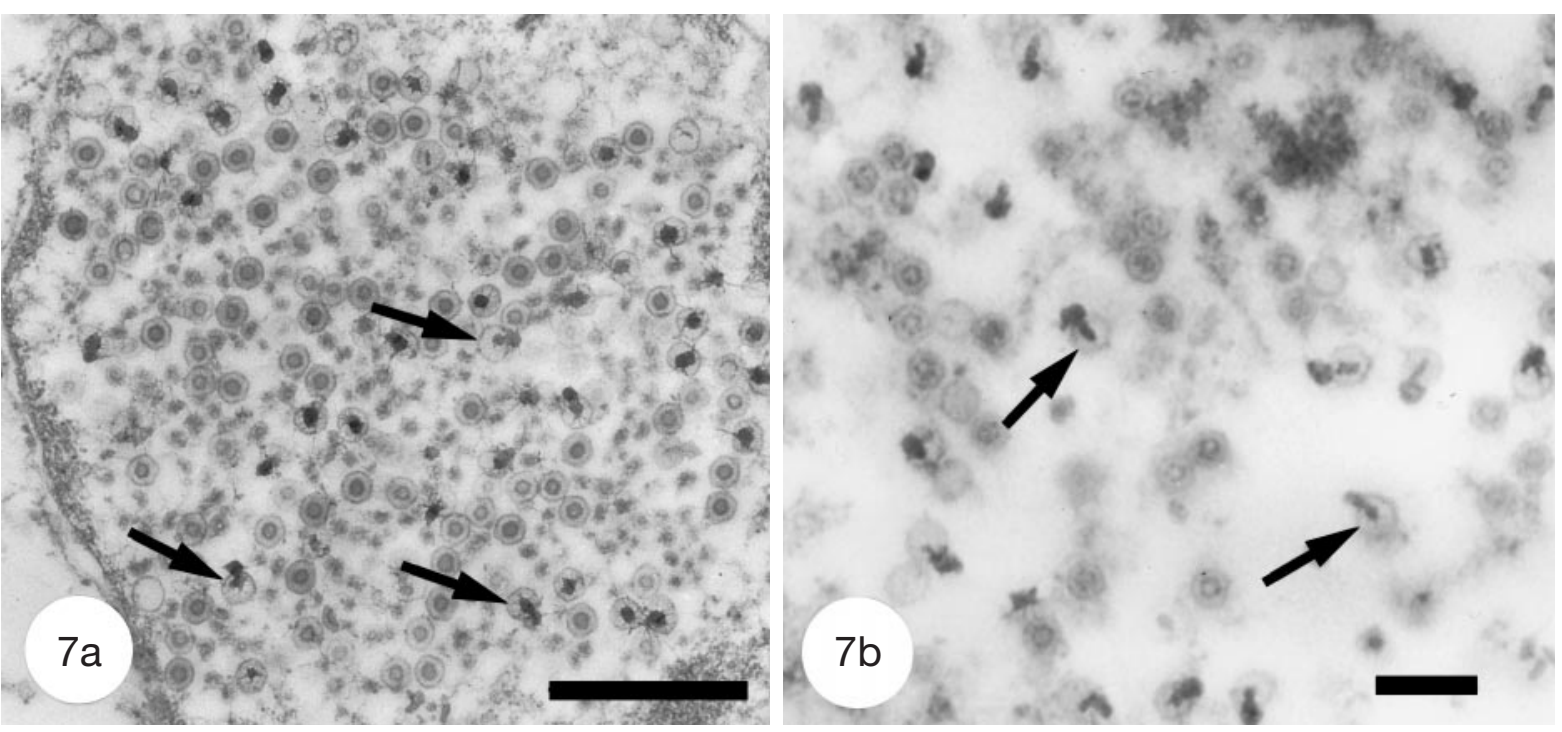

Fig. 7. Entry of nucleoids into capsids (arrows) with fibrils apparently extending into and out of the capsids. (a) Crassostrea gigas spat, scale bar $=500 \mathrm{~nm}$. (b) Ostrea edulis spat, scale bar $=200 \mathrm{~nm}$

\section{DISCUSSION}

The virus particles described herein in Crassostrea gigas and Ostrea edulis oysters resemble vertebrate herpesviruses in size, in capsid genesis and in the fact that they possess a regular icosahedral capsid, toroidal core and envelope (Roizman 1982, 1990, Roizman \& Baines 1991). The observation of Feulgen's stain positive cytoplasmic and nuclear components in the infected cells is in accordance with herpesviral infections. In addition, the fibrils running from the inner surface of the capsid to the nucleoid are similar to the arrangement in herpes virions (Furlong et al. 1972, Roizman 1990). However, nucleocapsids of oyster viruses described in this study are not surrounded by a developed tegument, contrary to most viruses belonging to the Herpesviridae family. This difference may be due to sample preparation (Valicek \& Smid 1976). Moreover, teguments are known to vary in size for different members of the Herpeviridae family (Roizman \& Furlong 1974, O'Callaghan \& Randall 1976, Spear \& Roizman 1980).

In thin-tissue sections of infected larvae and spat of both oyster species, nucleocapsids occur in a variety of morphological forms. Essentially, 2 classes of capsid types are seen in herpes-like virus infected oyster cells. Some capsids can be referred to as empty because they exhibit no internal ultrastructure and lack an electron-dense core. The second class of nucleocapsids contains some type of internal struc-
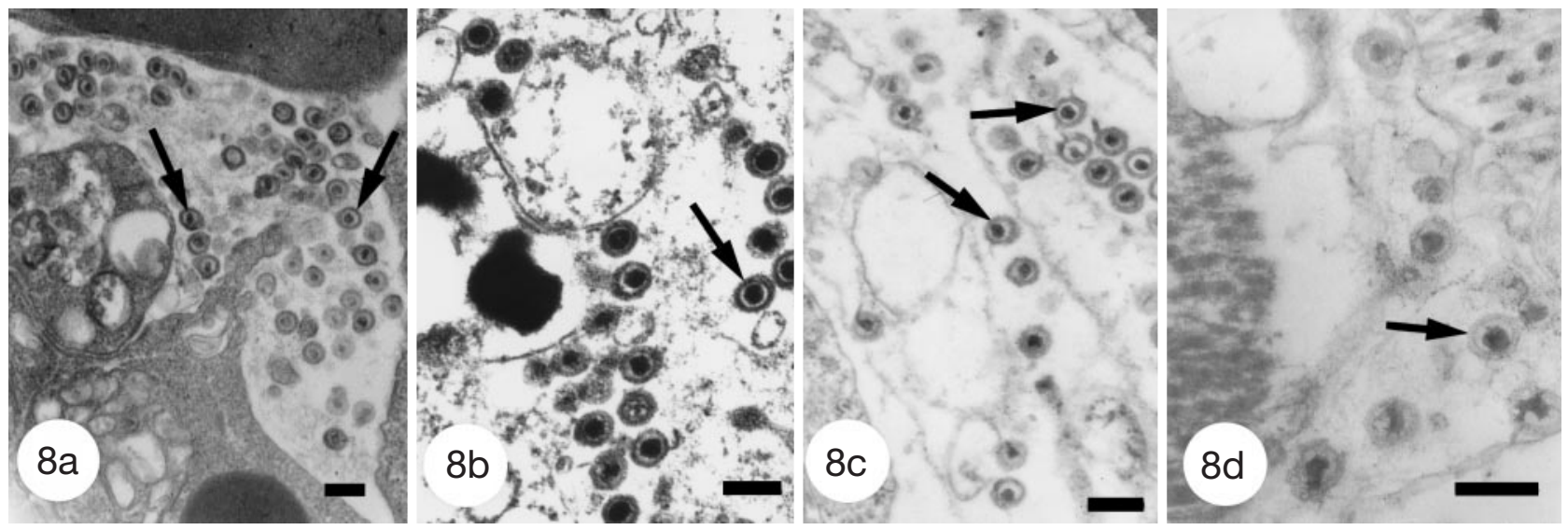

Fig. 8. Extracellular enveloped virus particles (arrows). (a) Crassostrea gigas larva, scale bar = 200 nm. (b) Crassostrea gigas spat, scale bar $=200 \mathrm{~nm}$. (c) Ostrea edulis larva, scale bar $=200 \mathrm{~nm}$. (d) Ostrea edulis spat, scale bar $=200 \mathrm{~nm}$ 

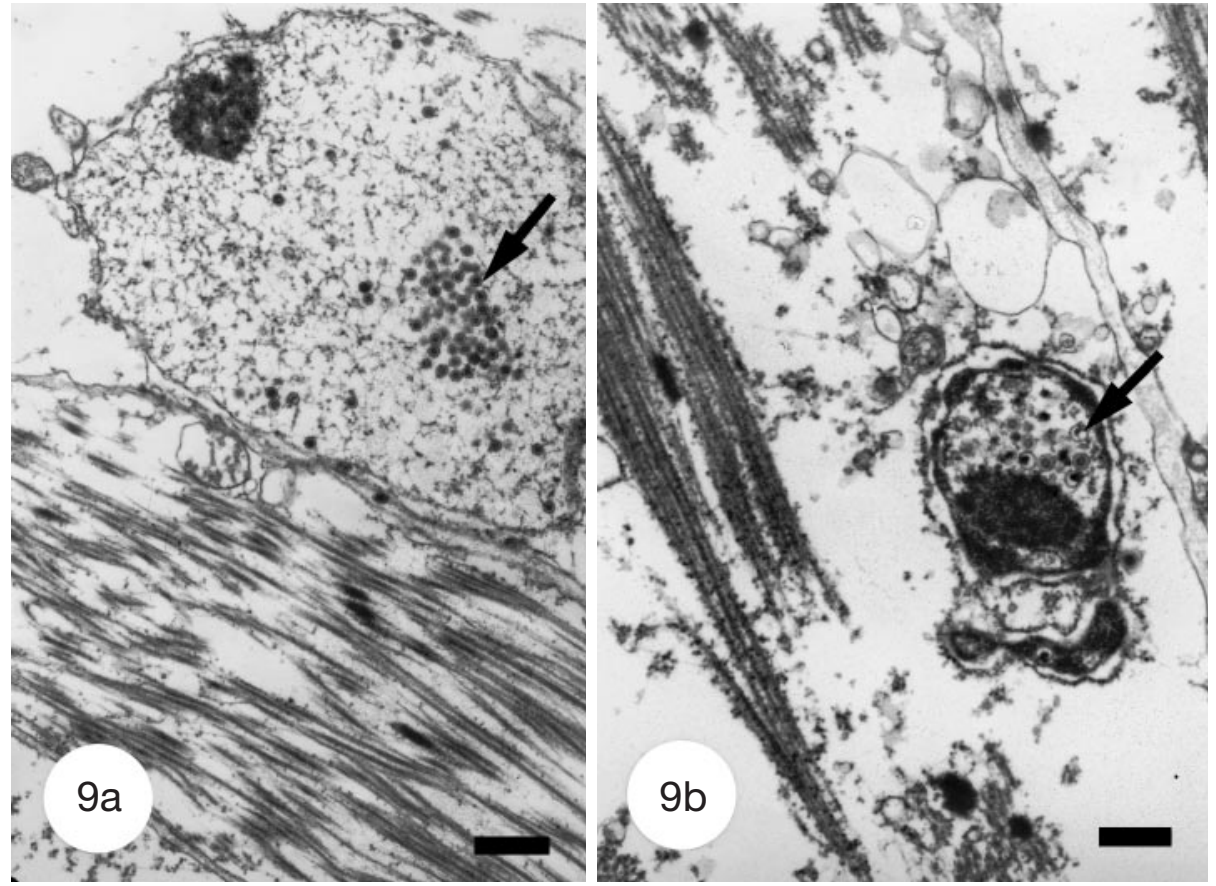

Fig. 9. Infected myocytes showing intranuclear nucleocapsids (arrows). (a) Crassostrea gigas spat, scale bar $=500 \mathrm{~nm}$. (b) Ostrea edulis spat, scale bar $=500 \mathrm{~nm}$

ture and include a variety of capsid types: toroidal core containing capsids, capsids with an electronlucent, cross-shaped internal structure and capsids that appear as 2 concentric ring structures; other forms may reflect different angles of sectioning through a maturing capsid. Electron microscopical examinations of infected cells in both Crassostrea gigas and Ostrea edulis suggest that empty capsids accept the virus DNA molecule and that DNA is packaged into a toroidal structure, thereby forming a mature capsid. Empty capsids are also a frequent finding, which may reflect a discrepancy between the production of virus DNA and structural proteins (Klussmann et al. 1997).

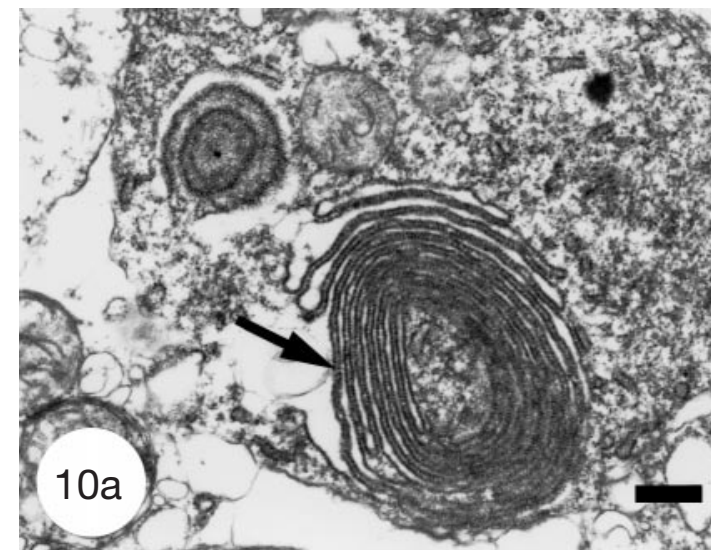

After replication of the virus, the assembled nucleocapsids of herpesviruses acquire envelopes from the inner lamella of the nuclear, cytoplasmic or cell membranes. Two mechanisms have been described for the envelopment process of herpesvirus capsids (Roizman 1982). One mechanism is the budding of mature nucleocapsids through modified areas of the inner lamella of the nucleus membrane (Fong et al. 1973). This budding process is rarely observed for herpes-like virus in infected cells of both Crassostrea gigas and Ostrea edulis. The rarity of virions in the perinuclear space may reflect either a rapid passage of particles from the nucleus to cytoplasm or low-grade virus replication. The second mechanism involves the apparent prolifer-

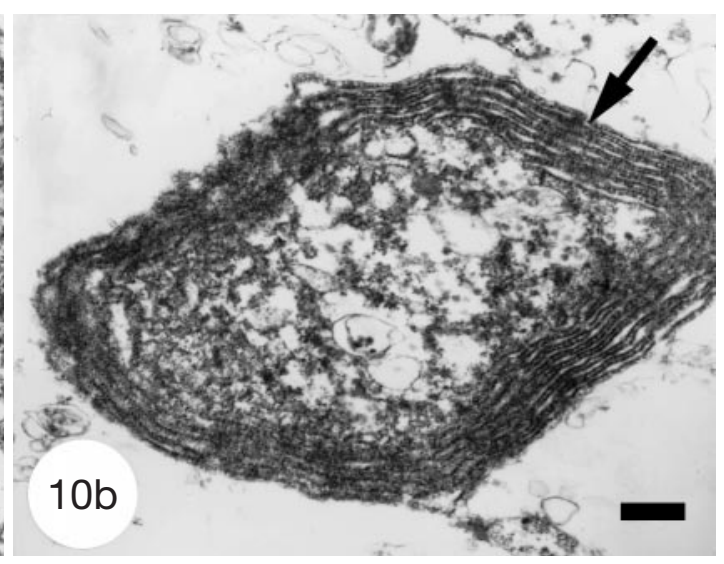

Fig. 10. Abnormal accumulation and reduplication of granular endoplasmic reticulum (arrows). (a) Crassostrea gigas spat, scale bar $=500 \mathrm{~nm}$. (b) Ostrea edulis spat, scale bar $=500 \mathrm{~nm}$ 

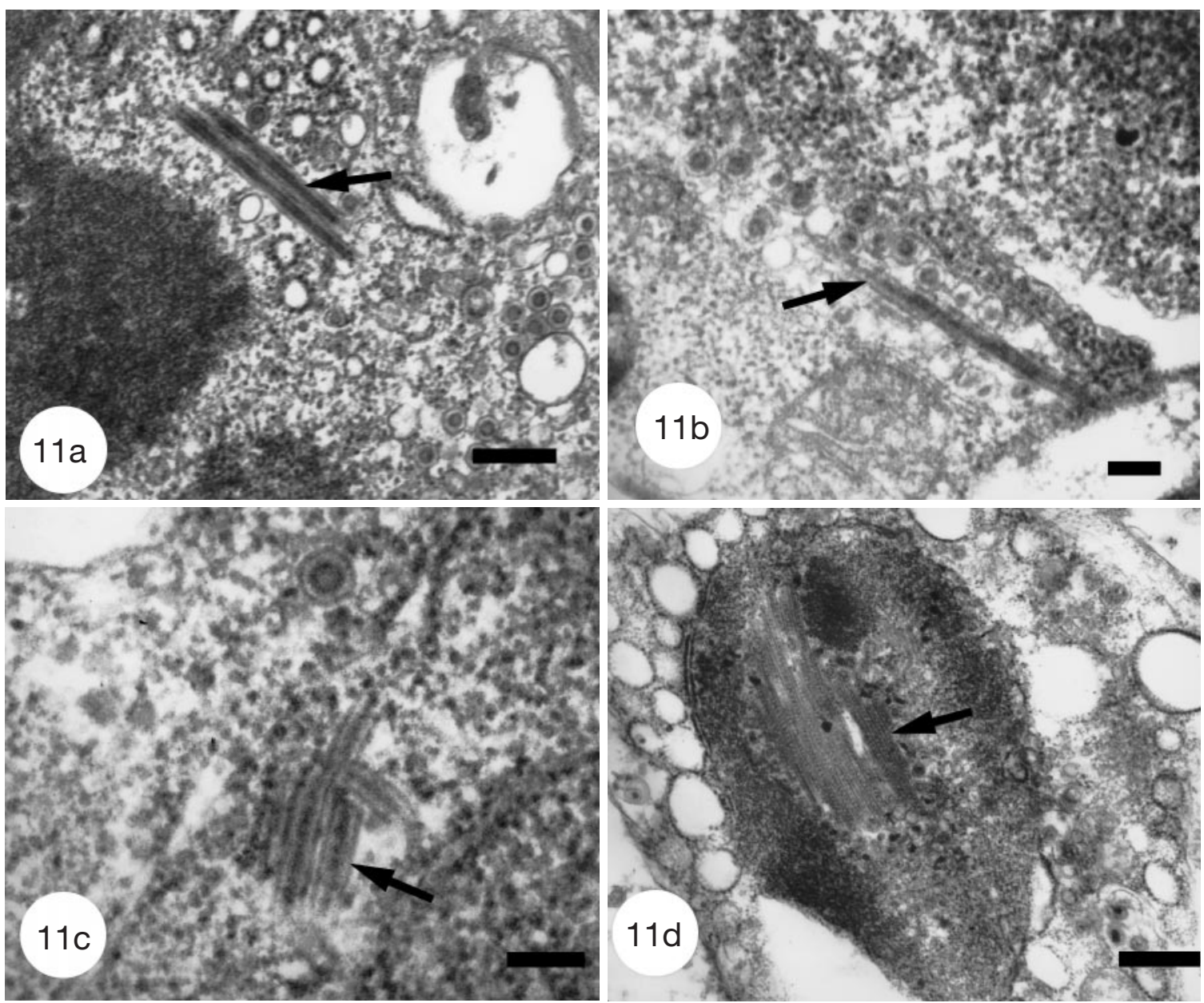

Fig. 11. Tubular structures (arrows). (a) Crassostrea gigas larva, scale bar = $200 \mathrm{~nm}$. (b) C. gigas spat, scale bar $=200 \mathrm{~nm}$. (c) Ostrea edulis larva, scale bar $=500 \mathrm{~nm}$. (d) $O$. edulis spat, scale bar $=100 \mathrm{~nm}$

ation of the nuclear membranes that react with and thereby envelop mature nucleocapsids (Dargan 1986, Nii 1992, Klussmann et al. 1997). Convoluted endoplasmic reticulum and perinuclear membranes are prominent in the cytoplasm of virus-infected cells in $C$. gigas and $O$. edulis spat. Budding of nucleocapsids into vesicles may be supported by vesicular and nuclear membrane reduplication, increasing the chance of virus particle attachment to vesicular membranes. Vesicles can serve as carriers for virus particles to the cell membrane, where after fusion of vesicular and cytoplasmic membranes mature virions are released. Accumulations of naked nucleocapsids in the stroma of infected oyster cell cytoplasm were reported in both oyster species in larvae and spat and can be interpreted as advanced stages of cytopathic changes (Friedmann et al. 1976, Tralka et al. 1977). Extracellular naked nucleocapsids were also observed in both oyster species and may derive from lysed infected nuclei.
Tubular structures were described from herpes-like virus infections of adult Crassostrea virginica (Farley et al. 1972), in the larval stages of the flat oyster Tiostrea chilensis (Hine et al. 1998) and in ranid herpesvirus 1 infections (Stackpole \& Mizell 1968). The tubular structures were composed of an outer tubule that was 45 to $55 \mathrm{~nm}$ in diameter containing a tubular core $25 \mathrm{~nm}$ in diameter and have been observed in both larvae and spat Crassostrea gigas and Ostrea edulis. Hine et al. (1998) described the presence of the tubular structures in order to contrast virogenesis in T. chilensis from herpes-like infections of other oyster species. The observation of these structures in herpes-like virus infections of C. gigas and O. edulis in France suggest that tubule presence or absence is not different depending on the host species.

Cell shrinkage and distinctive condensation of the chromatin in some nuclei are observed in infected oyster hemocytes belonging to both Crassostrea gigas and Ostrea edulis. These changes are typical morpho- 
logical characteristics of cells undergoing apoptosis in vertebrates and invertebrates (Ellis \& Horvitz 1986, Arends \& Wyllie 1991, Feldmann 1995). Increasing evidence indicates that apoptosis may occur during several viral infections, including those caused by members of the Herpesviridae family (Krueger et al. 1995, Hanon et al. 1996, Koyoma \& Miwa 1997, Mastino et al. 1997, Wilson et al. 1997). However, herpesviruses have been shown to induce as well as block apoptosis with the outcomes depending on the target cell type and the infection conditions (Chou \& Roizman 1992, Kieff \& Sherik 1998). Apoptosis may also occur during herpeslike virus infections in oysters and play a role in mechanisms involved in virus infection restriction or latency as has been described in several viral infections in vertebrates (Sadzot-Delvaux et al. 1995).

The herpes-like viruses associated with mortalities among hatchery-reared and nursery-cultured spat in both Crassostrea gigas and Ostrea edulis appear to be morphologically related. They have the same structural characteristics, the same cellular localizations with a high tropism for fibroblastic-like cells and comparable sizes (Table 1). The observation of mortality in association with the detection of virus particles first in one oyster species and a few days later in the other one underlines the assumption that the herpes-like viruses described in C. gigas and $O$. edulis may be the same one. Interspecific transmission may occur efficiently under hatchery and nursery rearing conditions. This possible interspecific transmission was previously investigated by Le Deuff (1995), who reported the transmission of herpes-like virus infection to healthy axenic C. gigas larvae using infectious material obtained from diseased European flat oyster larvae.

We describe for the first time, in this study, the presence of a herpes-like virus in French European flat oyster larvae associated with high mortality rates. The morphological characteristics of viruses observed simultaneously in larvae and spat of both species Crassostrea gigas and Ostrea edulis are close to those of the viruses detected among oysters belonging to different species. The nucleocapsids are similar in dimension to those detected in Pacific oyster larvae in French hatcheries (Nicolas et al. 1992), in French Pacific oyster spat (Renault et al. 1994a), in European flat oyster spat (Comps \& Cochennec 1993) and in adult Eastern oysters (Farley et al. 1972). Mature virions described in this study are similar in size to those detected in Pacific oyster larvae in New Zealand (Hine et al. 1992) and in France among Pacific oyster spat and larvae (Renault et al. 1994a,b).

Virus purification and virus DNA extraction are necessary to develop specific molecular probes and to identify the viruses detected in different oyster species. The recent herpes-like purification and virus
DNA extraction (Le Deuff \& Renault 1999) will permit determination of the genome structure and restriction enzyme maps in order to compare together viruses observed in different oyster species.

Acknowledgements. This study could not been completed without the valuable help of some private French hatcheries. The authors acknowledge J. P. Baud (IFREMER Bouin) for providing biological material. This research was supported in part by the Conseil Général de la Charente Maritime and the Région Poitou-Charentes.

\section{LITERATURE CITED}

Arends MJ, Wyllie AH (1991) Apoptosis: mechanisms and roles in pathology. Int Rev Exp Pathol 32:223-254

Chou J, Roizman B (1992) The $\gamma 134.5$ gene of herpes simplex virus 1 precludes neuroblastoma cells from triggering total shuoff of protein synthesis characteristic of programmed cell death in neuronal cells. Proc Natl Acad Sci USA 89: 3266-3270

Comps M, Cochennec N (1993) A herpes-like virus from the European oyster Ostrea edulis L. J Invertebr Pathol 62: 201-203

Dargan DJ (1986) The structure and assembly of herpesviruses. In: Harris JR, Horne RW (eds) Electron microscopy of proteins. Academic Press, London, p 359-437

Ellis HM, Horvitz HR (1986) Genetic control of programm death in the nematode Caenorhabditis elegans. Cell 44(6): $817-829$

Farley CA, Banfield WG, Kasnic JRG, Foster WS (1972) Oyster herpes-type virus. Science 178:759-760

Feldmann G (1995) L'apoptose ou mort cellulaire programmée. Ann Pathol 15(1):92-109

Fong CK, Tenser RB, Hsiung GD, Gross PA (1973) Ultrastructural studies of the envelopment and release of guinea pig herpes-like virus in cultured cells. Virology 52:468-477

Friedmann A, Coward JE, Morgan C (1976) Electron microscopic study of the development of Herpesvirus saimiri. Virology 69:810-819

Furlong D, Swift H, Roizman B (1972) Arrangement of herpesvirus deoxyribonucleic acid in the core. J Virol 10: 1071-1074

Gabe M (1968) Détection histochimique des nucléoprotéines et des métalloprotéines. In: Masson et Cie (eds) Techniques histologiques. Jouve, Paris, p 553-558

Hanon E, Vanderplasschen A, Lyaku J, Keil G, Denis M, Pastoret PP (1996) Inactivated bovine herpesvirus 1 induces apoptotic cell death of mitogen-stimulated bovine peripheral blood mononuclear cells. J Virol 70(6):4116-4120

Hine PM, Thorne T (1997) Replication of herpes-like viruses in haemocytes of adult flat oysters Ostrea angasi (Sowerby, 1871): an ultrastructural study. Dis Aquat Org 29(3):197-204

Hine PM, Wesney B, Hay BE (1992) Herpesvirus associated with mortalities among hatchery-reared larval Pacific oysters Crassostrea gigas. Dis Aquat Org 12(2):135-142

Hine PM, Wesney B, Besant P (1998) Replication of herpeslike viruses in larvae of the flat oyster Tiostrea chilensis at ambient temperatures. Dis Aquat Org 32(3):161-171

Kieff E, Sherik T (1998) Modulation of apoptosis by herpesviruses. Semin Virol 8:471-480

Klussmann JP, Krueger E, Sloots T, Berneman Z, Arnold G, 
Krueger GRF (1997) Ultrastructural study of human herpesvirus-7 replication in tissue culture. Virchows Arch 430:417-426

Koyoma AH, Miwa Y (1997) Suppression of apoptotic DNA fragmentation in herpes simplex virus type 1-infected cells. J Virol 71(3):2567-2571

Krueger GR, Buja LM, Rojo J, Lasch J, Koch B, Leyssens N (1995) Apoptosis and cell proliferation in HHV-6 infections. Regulatory mechanisms of p53/bcl-2/ras interactions. Pathologe 16:120-127

Le Deuff RM (1995) Contribution à l'étude de virus de mollusqies marins apparentés aux Iridoviridae et aux Herpesviridae. Thèse de doctorat. Université de Bordeaux II

Le Deuff RM, Renault T (1999) Purification and partial genome characterization of a herpes-like virus infecting the japanese oyster, Crassostrea gigas. J Gen Virol 80: $1317-1322$

Mastino A, Sciotino MT, Medici MA, Perri D, Ammendolia M G, Grelli S, Amici C, Pernice A, Guglielmino S (1997) Herpes simplex virus 2 causes apoptotic infection in monocytoid cells. Cell Death Differ 4:629-638

Nicolas JL, Comps M, Cochennec N (1992) Herpes-like virus infecting Pacific oyster larvae, Crassostrea gigas. Bull Eur Assoc Fish Pathol 12(1):11-13

Nii S (1992) Electron microscopic study on the development of herpesviruses. J Electron Microsc 41:414-423

O'Callaghan DJ, Randall CC (1976) Molecular anatomy of herpes viruses: recent studies. Prog Med Virol 22:152-165

Renault T, Cochennec N, Le Deuff RM, Chollet B (1994a) Herpes-like virus infecting Japanese oyster (Crassostrea gigas) spat. Bull Eur Assoc Fish Pathol 14(2):64-66

Renault T, Le Deuff RM, Cochennec N, Maffart P (1994b) Herpesviruses associated with mortalities among Pacific

Editorial responsibility: Albert Sparks,

Seattle, Washington, USA oyster, Crassostrea gigas, in France-comparative study. Rev Méd Vét 145(10):735-742

Roizman B (1982) The familly Herpesviridae. General description, taxonomy and classification. In: Roizman B (ed) The viruses, Vol 1. Herpesviruses. Plenum Press, New York, p 1-23

Roizman B (1990) Herpesviridae: a brief introduction. In: Fields BN, Knife DM (eds) Virology. Raven Press, New York, p 1787-1793

Roizman B, Baines J (1991) The diversity and unity of Herpesviridae. Comp Immun Microbiol Infect Dis 14(2):63-79

Roizman B, Furlong D (1974) The replication of herpesviruses. In: Fraenkel-Conrat H, Wagner RR (eds) Comprehensive virology, Vol 3. Plenum Press, New York, p 229-403

Sadzot-Delvaux C, Thonard P, Schoobroodt S, Piette J, Pentier B (1995) Varicella-zoster virus induces apoptosis in cell culture. J Gen Virol 76:2875-2879

Spear PG, Roizman B (1980) Herpes simplex viruses. In: Tooze J (ed) Molecular biology of tumors viruses, Part 2, DNA tumor viruses. Cold Spring Harbor Laboratory, New York, p 15-745

Stackpole CW, Mizell M (1968) Electron microscopic observations on herpes-type virus-related structures in the frog renal adenocarcinoma. Virology 36:63-72

Tralka TS, Costa J, Rabson A (1977) Electron microscopic study of Herpesvirus saimiri. Virology 80:158-169

Valicek L, Smid B (1976) Envelopment and the envelopes of infectious bovine rhinotracheitis virus in ultrathin sections. Arch Virol 51:131-145

Wilson SE, Pedroza L, Beuerman R, Hill JM (1997) Herpes simplex virus type-1 infection of corneal epithelial cells induces apoptosis of the underlying kertocytes. Exp Eye Res 64:775-779

Submitted: January 18, 2000; Accepted: August 8, 2000 Proofs received from author(s): September 14, 2000 